\section{Erika Lemmer}

Erika Lemmer is verbonde aan die Departement Afrikaans en Algemene Literatuurwetenskap, Universiteit van Suid-Afrika.

E-pos:lemmee@unisa.ac.za

\section{'An entangled bank': Evolusionêre patrone in die Winterbach-tweeluik Klaaglied vir Koos en erf}

'An entangled bank': Evolutionary patterns in Winterbach's diptych Klaaglied vir Koos

and erf

The novels of the contemporary Afrikans writer, Ingrid Winterbach, display a distinctive predisposition towards natural history and Darwinian ideas. Her fictionalisation of a nineteenth-century worldview is underpinned by an imaginative (neoVictorian) exploration of Darwinian concepts such as growth, metamorphosis, transformation and evolution. In his study on the Darwinian imagination in Victorian fiction, George Levine identifies a gestalt of ideas (both detectable in novels and in science) which can be regarded as central to the Darwin project. Darwin's metaphor of an entangled bank (which depicts life as an overcrowded space where numerous species compete, diversity and reproduce in a struggle for survival) will be specifically assessed in this evocritical reading of Winterbach's earlier publications, Klaaglied vir Koos ("Dirge for Koos", 1984) and erf(1986). Keywords: Afrikaans novels, Darwin in fiction, evolutionary narratives, Ingrid Winterbach, Lettie Vilioen, (neo-)Victorian studies.

It is interesting to contemplate an entangled bank, clothed with many plants of many kinds, with birds singing in the bushes, with various insects flitting about, and with worms crawling through the damp earth, and to reflect that these elaborately constructed forms, so different from each other, and so dependent on each other in so complex a manner, have all been produced by laws acting around us.

- Charles Darwin, On the origin of species (1859)

\title{
Inleiding
}

In die huidige tydsgewrig, soos gedurende die Wetenskapsera van 1789-1914 (en spesifiek die Victoriaanse periode vanaf 1837-1901), is daar opnuut'n opsigtelike interaksie tussen die wetenskap en die letterkunde. Hierdie waarneming word ondersteun deur kritici soos Gillian Beer, David Knight, George Levine (1-9), 
Elaine Shaffer en Sally Shuttleworth (147-61)—almal bekende navorsers binne die gevestigde navorsingsterrein van die letterkunde en wetenskap ("literature and science"). Die eietydse toenadering tussen dié twee dissiplines word dan ook dikwels deur hierdie kritici beskryf met die frase "retro- of neo-Victoriaans."

John Brockman munt selfs die term "derde kultuur" vir hierdie scenario waar die letterkunde en die wetenskap—soos in Victoriaanse tye-amper as organiese eenheid binne die samelewing funksioneer. Die term "derde kultuur" is uiteraard ' $n$ toespeling op die bekende debatte van Matthew Arnold en Aldous Huxley (1880 - 82) en F.R. Leavis en C.P. Snow (1959-63), waar die status en wisselwerking van die sogenaamde "twee kulture" (naamlik die letterkunde/kunste en die wetenskap) beredeneer is. Die Victoriaanse periode is veral gekenmerk deur die heftige reaksie wat Darwin se evolusieleer in die burgerlike samelewing ontlok het. Heersende debatte rondom evolusie, Intelligente Ontwerp en kreasionisme getuig daarvan dat die evolusieleer vandag steeds in die eietydse verbeelding geproblematiseer word en die bestaan van'n omvangryke Darwin-industrie noop dus'n verkenning van die wyse waarop' $n$ Darwin-paradigma in die kontemporêre letterkunde neerslag vind.

Ingrid Winterbach (ook onder haar pseudoniem Lettie Viljoen) se romanmatige verkenning van hierdie tersaaklike "tussenterrein" —-soos wat daar in Belemmering verklaar word-strek deurlopend vanaf haar debuut, Klaaglied vir Koos in 1984 tot by haar nuutste publikasie, Die aanspraak van lewende wesens in 2012 (Lemmer, "Ingrid Winterbach"). Sy word alreeds sedert haar debuutwerk, Klaaglied vir Koos deur André P. Brink (“Beste prosa”) uitgesonder as'n romanskrywer wat'n preokkupasie met wetenskaplike prosesse en wetenskaplike benoeming vertoon. Haar tekste word deur Louise Viljoen as "scientifically detailed, microphysical" bestempel. Joan Hambidge vestig weer die aandag op Winterbach se narratiewe strategie om belewenisse deurentyd in terme van die biologiese te beskryf. J.C. Kannemeyer toon tereg aan dat' $n$ teks soos Karolina Ferreira vanweë die fiksionalisering van'n wetenskaplike wêreldbeeld "in die trant van die negentiendeeeuse romankuns staan". Ena Jansen (734) beklemtoon ook Winterbach se strewe na wetenskaplike eksaktheid wanneer sy die feitelike aandag vir insekte, argeologie, geologie, fauna, flora, die beeldende kuns en geskiedenis as opvallende aspekte van haar romankuns uitsonder.

Winterbach se sintuig vir die wetenskaplike word bevestig deur die veelvuldige wetenskaplike betekenisdraende newetekste in haar romans asook deurlopende verwysings na metamorfose, evolusie en ander oorsprongsteorieë. Charles Malan verwys byvoorbeeld na Belemmering as' $\mathrm{n}$ "genealogiese gids wat jou baie vertel oor jou band met jou grootmoeder en jou voorsate, die visse, dinosourusse, ape". In Die boek van toeval en toeverlaat bereik die fassinasie met oorspronge en evolusionêre teorieë' $n$ hoogtepunt en hierdie roman word dikwels deur kritici uitgesonder as 'n eksemplariese voorbeeld van Winterbach se strategie om 
natuurhistoriese kennis in haar romankuns te bevoorgrond (Van den Heever; Van Vuuren; Louise Viljoen).

In onderhoude bevestig Winterbach haar bewondering vir die skoonheid van natuurlike voorwerpe en die natuurlike wêreld (Lemmer, "Gesprek"). Sy dui aan dat die wetenskap vir haar 'n "skoner", meer kliniese opsie as die kunste verteenwoordig, maar dat albei dissiplines wél ryk bronne is waaruit sy inspirasie vir haar eie skryfwerk én visuele kuns put. Winterbach erken aan die joernalis Fred de Vries dat die spanning tussen "knowledge and something less rationally interpretable" ' $\mathrm{n}$ herhalende tema in haar werk is en bevestig daarmee haar bevraagtekening van die tradisionele grense tussen verskillende sfere en dissiplines. Sy spreek haar soos volg uit oor haar eie didaktiese ingesteldheid: "Ek fantaseer dat dit stil word, dat ek u meevoer, op' $n$ tog neem, dat ek u delight en u verras. Dat ek u onderrig selfs, dat ek'n edifying discourse lewer" (Viljoen, "Bodemlose put", my kursivering). Hierdie kunsteoretiese uitspraak van Winterbach strook trouens met die Victoriaanse kennisideaal wat ook daarop gerig was om terselfdertyd te onderrig en te vermaak.

Winterbach se veelvuldige gebruik van wetenskaplike intertekste sal vervolgens met spesifieke verwysing na haar vroeëre werk, naamlik die diptiek of tweeluik, Klaaglied vir Koos en erf, ondersoek word. Die klem sal oorwegend val op daardie romanverwysings wat, in navolging van A.S. Byatt, as breedweg Darwinisties getipeer kan word met die oog daarop om die artistieke funksionaliteit daarvan te probeer peil.

\section{Die Gestalt van Darwinistiese idees}

In'n uitspraak wat as inleidende motto hierbo aangehaal word, verduidelik Charles Darwin sy evolusieteorie deur die lewe metafories te beskryf as' $n$ oorbegroeide rivieroewer ("an entangled bank") waar'n verskeidenheid interafhanklike spesies, uitgelewer aan natuurwette, voortdurend moet meeding, verander en aanpas om te kan oorleef. Winterbach herwin byvoorbeeld in Landskap met vroue en slang op treffende wyse die Darwinistiese metafoor van die oorbevolkte rivieroewer en bevestig daarmee die voortgesette gesprek met Darwin wat deurgaans in haar oeuvre aantoonbaar is:

Die sensasie van beklemming, van 'n gebrek aan ruimte het nie net te make daarmee dat die koepel van die hemel hier oënskynlik swaarder, drukkender op die aarde rus nie, maar met die gevoel dat daar 'n groter verskeidenheid uiteenlopende vorms en manifestasies van bewussyn om suurstof en leefruimte in hierdie troebel sop meeding. [...] In die lug is daar die dreigende weldadigheid van die groeiseisoen. 'n Wurm op'n varing beweeg energiek met die netnerwige stingel langs. Onder alle klippe en blombakke maak die miere driftig nes; hulle versorg hulle miereiers en vreet lustig aan die gras. Die lug knetter van die vlerkgeklap 
OORGANGE EN VOORTGANGE: 'n Huldigingsbundel vir C. H. F. Ohlhoff

van gepantserde insekte. Onder elke klip, agter elke blaar, intiem ingenestel, dig aangekruip in die skagte en blomme en oopvouende blare van elke plant, hou iets skuil. Waak iets, en neem waar. (my kursivering)

Dié metafoor van'n verstrengelde bos is trouens ook deur John Glendening benut in die titel van sy werk oor die evolusionêre verbeelding in laat-Victoriaanse naturalistiese romans, naamlik The Evolutionary Imagination in late-Victorian Novels: an Entangled Bank. Levine (119) identifiseer onder meer vir Charles Dickens en George Eliot (na wie daar verskeie intertekstuele verwysings in die Winterbachoeuvre voorkom) as "the great novelists of entanglement"; skrywers wat selfs in stedelike landskappe daardie konneksies van interafhanklikheid en genealogie gevind het wat Darwin se rivieroewer kenmerk.

On the Origin of Species by means of Natural Selection or the Preferred Race in the Struggle for Life verskyn in 1859 en oefen'n beduidende invloed uit op die Victoriaanse burgerlike samelewing, en spesifiek ook op die letterkunde van daardie era (Paradis en Postlewait). George Levine formuleer in sy inleiding tot Darwin and the Novelists: Patterns of Science in Victorian Fiction (1988) derhalwe "a gestalt of the Darwinian imagination; a gestalt detectable in novels as well as in science" (10) wat volgens hom die essensie van die Darwin-projek onderlê.

Levine (Darwin) meen dat die evolusieteorie daartoe gelei het dat die menslike subjek se rangorde in die natuur heroorweeg is. Wetenskaplike observasie is beskou as'n metode waarmee feite in kennis verander kon word en waar sodanige kennis dan weer' $n$ vorm van mag sou veronderstel. Die geoloog Charles Lyell se teorie van geleidelike verandering het as basiese model vir die evolusieleer gedien en verder gelei tot die idee dat alle gebeure as oorsaaklik en verklaarbaar vanuit die wetenskap (eerder as die teologie) geag is. Binne hierdie denke is alles onderhewig aan potensiële verandering en niks kan begryp word sonder die voorafgaande geskiedenis nie. Die idee dat die kontinuïteit van tyd'n aspek van die kontinuïteit van lewe self is, het uiteindelik daartoe gelei dat die grense tussen spesies en variëteite begin vervaag het. Alle vorme van lewe word beskou as verwant aan mekaar in intrinsieke patrone van erflikheid en wedersydse afhanklikheid ("an entangled bank"). Om die lewe van' $n$ organisme effektief te kan beskryf, verg'n gelyktydige beskrywing van die vele ander vorme waarmee dit meeding en waarvan dit afhanklik is "in endless chains of connection" (Levine, Darwin 18).

Darwin se wêreld word uitgebeeld as een van oorvloed en selfs oorbevolking waar die oorlewing van spesies afhang van hulle vermoë om te kan kompeteer, varieer, diversifiseer en reproduseer-' $n$ gedagte wat Spencer met sy bekende frase "survival of the fittest" en Tennyson met sy "nature red in tooth and claw" wou verwoord. Die Darwin-narratief van voortdurende aanpassing impliseer nie ontwerp en opset nie, maar ontvou "natuurlik" volgens vasgelegde natuurwette, sonder enige eksterne inmenging of finale doelwit met die "willose" mens wat 
uitgelewer is aan erflikheid en omgewing (soos blyk uit die naturalistiese romantradisie). Die oënskynlike chaos in die natuur word onderlê deur ordelike natuurwette wat telkens afleibaar is uit betrokke natuurverskynsels en die essensiële rol van toeval as meganisme van verandering word beklemtoon wanneer geringe, toevallige en inkrementele veranderinge as die bron van alle evolusionêre variasie aangetoon word. In'n latere publikasie, Darwin loves you. Natural Selection and the Re-enchantment of the World (2006) voer Levine oortuigend aan dat die gees van disillusie wat as'n resultaat van Darwin se naturalistiese beskouing ontstaan het, hoegenaamd nie rekenskap gee van die verwondering waarmee die "romantiese Darwin" die natuurlike wêreld bejeën het nie.

Die gestalt van Darwinistiese beginsels soos hierbo uiteengesit (en veral die metafoor van die oorbegroeide rivieroewer) sal vervolgens as' $n$ vertrekpunt dien vir die bespreking van Darwinistiese patrone in die diptiek van Winterbach.

\section{Klaaglied vir Koos (Lettie Viljoen, 1984)}

Lettie Viljoen (die skrywersnaam waaronder Winterbach haar eerste vyf tekste publiseer) se debuutnovelle, Klaaglied vir Koos, verskyn in 1984 by die alternatiewe uitgewer Taurus en word oorwegend positief deur resensente ontvang. Literatore soos André P. Brink, Louise Viljoen en Joan Hambidge beklemtoon die outeur se gevoelige sintuig vir die wetenskaplike.

Die voorblad- en titelbladsketse is beide deur die reële outeur ontwerp en suggereer alreeds die wetenskaplike stramien waarop die verhaalgebeure grootliks gaan berus. Hambidge bestempel die skets op die voorblad as'n miernes met afskaduwings van'n mansgesig daarin. Die miernesgedagte korreleer met die idee dat die man in die verhaal op' $n$ politieke sending "ondergronds" gaan en word ondersteun deur die afbeeldings wat soos tonnels lyk asook enkele direkte verwysings in die teks na "'n duidelike beeld van'n miernes" (Hambidge). Op die titelbladsy verskyn 'n anatomiese deursnitskets van 'n oorkanaal met byskrifte in dieselfde handskrif as dié by die skets op die voorblad. Hambidge redeneer oortuigend dat die oor ("die soort wat mens in mediese en biologiese handboeke aantref") ' $n$ hoorder veronderstel en knoop dit direk aan die belydenisaard van die verhaal: die titel veronderstel immers ' $n$ klaaglied wat aangehoor moet word.

Die verhaalgebeure skarnier rondom die bestaan van'n naamlose vrouekarakter wie se man vanweë sy politieke oortuigings gedwing word om "ondergronds" te gaan ten einde sy stryd teen die heersende orde voort te sit (Van der Vyver). Dié idee van "ondergronds" word deurentyd verder uitgewerk in die metafoor van die termietnes. Venter tipeer die teks as' $n$ alternatiewe vorm van grensliteratuur waar die alternatiewe geskiedenis die kern van die verhaalgebeure vorm: die vrou wat agterbly met haar kind en tuin vol "beurende vrugbare vegetale lewe" (Brink, “Beste prosa"). 
Tydens haar man se afwesigheid knoop die vrou'n ander verhouding aan en soos Christelle Stander (47) tereg opmerk, word die roman 'n indringende verkenning van vroulike seksualiteit. Al die beskrywings van menslike seksuele omgang (Klaaglied 2,7) geskied egter in die kliniese, wetenskaplike toonaard van die teks:

Tydens die uiteindelike ejakulatoriese sametrekkings word die seminale vog deur die hele lengte van die uretra meatus geforseer, onder die swaar druk wat veroorsaak word deur die onwillekeurige, maar gekoördineerde sametrekkings van die spiergroepe sphincter urethrae, bulbospongiosus, ischiocavernosus, asook die oppervlak-, diep-dwars- en perinale spiere. (7)

Wanneer ook die minnaar haar verlaat, "raak sy toenemend afgesny" en wag op rigting soos wat "die Skoffelneushaai (Sphyrna zygaena) op reuk wag" (18). Leon Venter (10) toon aan dat die vrou in hierdie periode omring word met allerlei tekens van bedreigde lewe: kiewiete wat nesmaak in grasstroke waar munisipale werkers kom gras sny; sprinkane wat eiers op die paadjie na die wasgoeddraad lê en klein weerlose slakkies met deurskynende doppe:

Met die reën kom daar duisende klein slakkies uit. Geen manier waarop hulle hulleself kan beskerm nie. Die doppies is te broos, byna deurskynend. Swak evolusionêre aanpassing as jy dink aan die enorme Galapagosskilpad se massiewe, ondeurdringbare dop. (27)

Die verwysing na Galapagos is geensins toevallig nie, aangesien Darwin se ontdekking van uniek aangepaste spesies op dié eilande uiteindelik die bewyse gevorm het vir sy teorie oor evolusie by wyse van natuurlike seleksie ('n beskouing wat ook onderliggend is aan hierdie roman).

Verganklikheid en verval word verder sigbaar in die roes en klamheid teen die mure en die vrou se voortgesette pogings om die "ekologie van haar werf" (69) in stand te hou. Die Darwinistiese oorlewingstryd (en die "entangled bank"-metafoor) eggo in haar eie stryd om te probeer oorleef: "Die lewe is maar'n bos, dink ek. Dié wat nie sterk genoeg is nie, word gewoon ondertoe gedruk" (17). Sy verwens later selfs die "vervloekte plante wat sy moet voed of vrekmaak" (64). Nadat sy finaal misluk om die kikoejoe in bedwang te hou, word dit uitgehaal en sy bewonder vervolgens die ryk insektelewe op die hardgebakte grond: sprinkane, spinnekoppe en krieke.

Allerlei vorms van biologiese lewe word dikwels met opgaaf van die Latynse spesiename op haas elke bladsy beskryf. Die vrou bejeën al hierdie uiteenlopende vorme van lewe met respek en erken daarmee' $n$ beginsel van biosentriese gelykheid waar die hiërargiese grense tussen spesies ondermyn word (ook'n uitvloeisel van die evolusieleer waar die mensspesie as onderdeel van die groter diereryk geklassifiseer word). In haar beskrywing van die vooruitstrewende dorp plaas sy 
dus almal op dieselfde vlak: "volop werkers, volop slakke, volop nuwe blare" (27).

Sy erken daarmee ook die intrinsieke waarde van alle lewe: sy is versigtig om nie op rysmiere te trap nie, red die spinnekoppe voordat sy die badwater intap, maak die budjie mak, en bid dat niemand die kiewiet en sprinkaan se eiers sal raaktrap nie. Beelde van groei, evolusie, aanpassing, metamorfose en transformasie—in beide politieke en persoonlike sin—kom, soos elders in die oeuvre, dikwels voor en vertoon in daardie opsig ooreenkomste met temas wat eie aan die Victoriaanse roman was. Brink ("Beste prosa” ) wys tereg op die verskillende stadia van ontwikkeling wat in hierdie teks aan die orde is (en saamval met die sikliese seisoensverloop): onvervulde verlange, afsterwing en afstomping; inkeer na binne en nuwe bewuswording. Hierdie metamorfose weerklink ook deur die teks in die talle gelykstellings tussen mens en insek: "Probeer jy die membraan van die kosmos prik? Ek voel hoe ek met harde, leeragtige vlerke soos 'n insek by die mure af beweeg. Ek probeer'n membraan breek: om in die bewussyn van die bewegende insek in te beweeg." (8)

Wanneer die naamlose vrou byvoorbeeld haar vriendin inlig oor die beeld van die miernes wat sy gesien het, bring dié dit dadelik in verband met die getalle en magsoorwig van die "swartes" (11); dit dui ook op ondergrawing en uitkalwing (20). Sy bieg self later: "In die hospitaal, toe die gesig van die miernes so intens een middag by my opgekom het, toe het dit gevoel asof ek met my oor teen die grond lê, en in die ondergrondse gange die gedruis van werkers hóór." (22)

Die vrouekarakter roep ook op'n later stadium haar man se les oor termiete in herinnering, naamlik "dat die termiete tuine maak in hulle neste onder die grond van die stukkies hout wat hulle versamel, en dat daar swamme hierop groei wat hulle as voedsel gebruik. Ek het gesê ek is spyt dat ek nooit die binnekant van'n miernes sal sien nie." (22) In die saadpakkies van die sprinkane sien sy ook die wapenopslagplekke van die politieke stryd; haar man hou hom (by wyse van spreke soos'n termiet) besig met allerhande "ondergrondse aktiwiteite". Hierdie aangehaalde gevalle is maar slegs enkele voorbeelde in die teks waar verskillende spesies (in ooreenstemming met tipiese negentiende-eeuse romanpraktyke) as onderling uitruilbaar voorgestel word.

Die vrou is boonop hiperbewus van die evolusionêre gang van die lewe, maar verloor selfs belangstelling in dié onderwerp wanneer sy depressief raak: "Eenmaal sou dit my geïnteresseer het hoe' $n$ black hole gevorm word, hoe skerpioene paar, die Natuur so ryk en sinvol, deel van'n groot bestemming. Nou skeel dit my nie'n moer nie." (22) Op aandrang van haar familie herwin sy egter uiteindelik weer haar belangstelling in die lewe en besluit om opnuut te begin. Sy verdiep haarself, as deel van hierdie transformasie- en bewuswordingsproses, opnuut in die aarde se oorsprongsgeskiedenis; die natuur word vir haar'n "bestemming":

Ek gaan kyk na 'n reeks films oor die lewe op aarde-hoe die lewe op aarde ontstaan het. Een uur per week stel ek myself nou (versigtig) bloot aan al die 
OORGANGE EN VOORTGANGE: 'n Huldigingsbundel vir C. H. F. Ohlhoff

vorms en prosesse van aanpassing, van evolusie. Om mee te begin, vind ek die visse 'n skrikwekkende vorm van bewussyn. [...] Droom oor plante, die oerplante: die konifers, die palms, Isastrea uit die Jura, 'n koloniale koraal (versteen soos 'n baarmoeder). Die koraal het in die vlak, arm waterpoele gegroei om die groot koraalriwwe te vorm. Kalkagtige alge vorm sagte rotslae in die kalkseë, tydens die Kryttydperk. Wat het gebeur met die verdonkerende aardbol, ná sy manjifieke vormingsgeskiedenis? [...] En tussen toe en nou: die pynlike en moeisame proses van metamorfose. Die herinnering is selektief, gekonsentreer soos urine. $(22,29)$

Snags lê sy en kyk na die spinnerakke (weer'n gewilde Victoriaanse kode). Sy besin oor die paarrituele van spinnekoppe en visualiseer hoe die mannetjies saggies aan die drade van die webbe pluk om aan die wyfies hulle bedoeling te sein (16). Sy verlang dan na haar man, maar beleef hom as so onbereikbaar soos "slym wat nie opgehoes kan word uit die bronchioli nie" (32). Dié gebruik van mediese terminologie is byvoorbeeld ook eie aan Eliot se romans en sluit verder aan by Winterbach se uitgesproke bewondering vir die klassieke Victoriaanse anatomiehandboek, Gray's Anatomy (1858).

Die vrou stel haar voor dat haar man in die bos oorleef op rysmiere, voëleiers, sprinkane, paddas of vlermuise. Sy beskryf vervolgens die verskillende vlermuisspesies met wetenskaplike presisie:

Is daar saans teen sonsondergang troppe migrerende vlermuise, hang hulle snags in digte trosse in die bome? Watter vreemde aanpassings sien hy? Miskien die vlermuis wat vrugte eet (Hypsignatus monstrosus) (die volwasse mannetjie het hoogs ontwikkelde stemorgane), miskien selfs die een wat visvang (Noctilio leporinus), of Taphozous perforatus, met die rooi vlerkafskeiding wat so sterk ruik (ondenkbaar!). (41)

Die vrouekarakter neem ook op ' $n$ stadium haar kind vir 'n uitstappie na die soölogiemuseum om te gaan kyk na "die goed in bottels" (53). Sy sien haarself en haar man in die laboratoriummonsters wat in flesse bewaar word:

Soos twee verkoolde monsters, menslike oorblyfsels van 'n natuurramp van vuur, in 'n fles van die een of ander biologiese aard en spesifikasie bewaar, omdat dié oorblyfsels hulle vorm beter behou het as steenkoolas. So lê ons ook verkool saam gebottel, embrionies, altyd maar simbioties verbind, asof dit ons onontkombare bestemming is. Ons onontsyferbare mompelings vir die nageslag niks meer nie as versteende of verkoolde borrels. (64)

Dié tipiese negentiende-eeuse gebruik van Winterbach om voorwerpe in verplaaste omgewings soos glasflesse en museums te plaas, is deurgaans opvallend en Andries Gouws (17) verwys in hierdie konteks na "die liggaam as anatomiese preparaat". 
Die apokaliptiese visie in die aanhaling hierbo word egter volgens Brink ("Beste prosa") in die slot van die verhaal opgehef deur 'n "visioen van menslike gemeensaamheid" waar talle keuses op die karakter wag (op die erf saam met haar man, die tuinier, die haweloses en ander spesies wat die teks bevolk).

Brink ("Beste prosa") verklaar die obsessie met wetenskaplike benoeming as'n poging om die spanning tussen die (vrou se) werklikheid en die afwesige werklikheid (van haar man ) spesifiek en by name op te roep deur te verwys na "feite, gegewens, gebeurtenisse en prosesse". So word die leser dan bewus gemaak van die naam as teken, as woord. Louise Viljoen ("Postcolonialism") bevestig dat hierdie verskille tussen die vrou en haar man 'n sentrale spanning in die teks aandui: hy bevind hom in die intellektuele en publieke (lees ook hier "wetenskaplike") domein; sy weer in die private en intuitiewe domein:

At certain points, the concentration on the private and personal becomes a preoccupation with the microphysical, as is evident from the scientifically detailed descriptions of sexual organs during intercourse. [...] The discourse of sexual submissiveness one finds elsewhere in the novel [...] is subverted by these moments of masculine scientific discourse in which the colonizing male gaze is momentarily returned. Thus the construction of the narrating subject at the intersection of race, gender, class and writing is interrogated on a thematic as well as a structural level. (My kursivering)

Namate die vrou dus ontvoog word van haar man, beheers sy die wetenskaplike diskoers met toenemende gemak. Uit die voorafgaande uitsprake van Brink en Louise Viljoen is dit duidelik dat die wetenskaplike beskrywings in Klaaglied vir Koos nie losstaan van die groter verhaalstruktuur nie, maar as ' $n$ integrale deel daarvan fungeer. Tipies van literêre tekste wat verteenwoordigend is van' $n$ derde kultuur, is daar hier ook' $n$ obsessie met oorsprongsgeskiedenisse en evolusionêre aanpassing. Die hoofkarakter se toenemende begrip vir die Darwinistiese proses manifesteer in'n nuutgevonde bewussyn:'n bewussyn waar brein en hart, intellek en intuïsie, wetenskap en mistiek uiteindelik simbioties saambestaan. Hierdie patrone word verder effektief ontgin in erf, die teks wat op Klaaglied vir Koos volg.

\section{$\operatorname{erf}$ (Lettie Viljoen, 1986)}

Winterbach se tweede novelle erf-weer onder die skrywersnaam Lettie Viljoenword, soos haar debuut, deur Taurus uitgegee en daar is soveel ooreenkomste met Klaaglied vir Koos dat dit op'n sekere vlak as'n pendant daarvan gelees kan word. Brink ("Novelle") wat die teks saam met die debuut as 'n diptiek (of tweeluik) beskryf, wys soos volg op die ooreenkomste: die verhaalgebeure sentreer hier ook rondom 'n vrou met 'n kind wat sonder'n man en "te midde van die tierende geilheid van die natuur' $n$ lewenspatroon probeer grondves". Die vrou se be- 
staansruimte word eweneens "bedreig en aangevul" deur'n plakker of plakkers op die erf; verhoudings word hier ook in meditasies gevisenteer; ook hier "broei dieselfde brandende seksualiteit onder die oppervlak van'n skerp intellektueel waargenome wêreld" (my kursivering).

Zelig (15) bestempel erf as die vroulike perspektief op'n heersende politieke klimaat: “Die skerp diskursiewe aanbod word afgewissel deur bykans inkantiewe fantasievlugte, meditasies - selfs skisofreniese drome. Intellek word telkens teenoor fantasie geplaas, die harde werklikheid teenoor die private droom." In hierdie verband word die patroon wat voorheen by Klaaglied vir Koos geïdentifiseer is (naamlik' $n$ voortdurende fluktuering tussen intellek en emosie, wetenskap en mistiek, rede en droom) ook in erf voortgesit.

Die mens se onderworpenheid aan die natuurwette staan, soos in die vorige teks, weer voorop: "Die natuur se magtige bestendigheid en die gewig van haar seisoene is onontkombaar." (erf 1) Hierdie naturalistiese veronderstelling word later herbevestig:

Alle gedrag word voortgebring (teweeggebring) deur neurologiese gebeurtenisse. Dit is moeilik om jou hierdie prosesse voor te stel. Die kennis is al onthutsend genoeg, dink Agnes. Dit is jammer dat sy haar oordeel en aanvoeling kwyt is, op dié manier begryp sy nooit wat aan die gebeur is nie. Die menslike brein is ' $n$ hand vol, nee seker twee hande vol hawermeelagtige stof, en dit kan sy eie werking betrag, dink sy." (15)

Soos in Klaaglied vir Koos is die hand van die implisiete outeur weer sigbaar in die invoeging van die newetekste, bandontwerp en keuse van motto's. Op die bandontwerp word die titel van erf byvoorbeeld direk opgevolg deur die invoeging van'n groen vierkant wat begrens word deur' $n$ swart raam (synde die voorstelling van'n omheinde erf). Die voorbladskets (weer deur Ingrid Scholtz) strek oor beide voor- en agterblad en stel'n stuk grond met skrapse vegetasie voor waar die begrensinge vaag, dog sigbaar is. Die vroulike hoofkarakter, Bets (en variante soos Agnes) se aktiwiteite binne die kontoere van die erf (wat hier mikrokosmos van die aarde word) moet volgens Brink ("Novelle") vertolk word as 'n simultane definiëring aan die kontoere van haar/hulle identiteit. Ten opsigte van die meerduidige titel erf, verwys die selfstandige naamwoord "erf" na'n stuk grond of perseel, terwyl die werkwoord "erf" natuurlik weer implikasies van afstamming inhou.

Links van die titelblad verskyn'n volblad-biologieskets van onder meer dorsale en ventrale aansigte van die wyfiespinnekop, asook van die boeklonge, vergesel van byskrifte soos "kaakkloue", "looppoot", ensovoorts (weer in dieselfde handskrif as dié by sketse in Klaaglied vir Koos). 'n Kernverwysing na spinnekoppe figureer prominent op bladsy 58 wanneer die spinnekop fyn waargeneem en beskryf word terwyl sy besig is om haar web te spin: 
'AN ENTANGLED BANK': Evolusionêre patrone in Klaaglied vir Koos en erf

Teen die verblekende maar intense lig sien Bets hoe dun sydraad uit die spinnekop se spintepels kom. Met haar agterpote bewerk sy die spindraad en met die voorpote haak sy die draad aan die vertikale drade van die raamwerk met 'n vinnige meganiese haak soos 'n hekelpen (teen daardie dramatiese lig). [...] Dan, as die spinnekop haar vertikale en konsentriese drade gespin het, sit sy die res van die nag bewegingloos in die middel van die web." (58-59)

Benewens ' $n$ natuurhistoriese ingesteldheid wat alreeds deur die skets vooruitgeloop word, is kritici dit eens dat die spinnekopmotief (soos ook in die Victoriaanse literatuur) belangrike leesleidrade verskaf. Vir Zelig dui die spinnerak op versplinterdheid; op'n onvermoë om die geheelbeeld te verskaf. Vanuit'n Darwinistiese gesigspunt kan dit dui op die interbetreklikheid van alle dinge; die moontlikheid van versoenbaarheid tussen oënskynlike disparaathede. Brink ("Novelle") meen dat dit'n "byna obsessionele narratiewe onderbewuste of gewete vir die gebeure" verteenwoordig. Hy dui verder aan dat die spinnekop altyd teen die ondergaande son afgeëts word en daardeur apokaliptiese dimensies aanneem ('n narratiewe element wat ook by Klaaglied vir Koos weerklank vind in die gepreserveerde laboratoriummonsters). Wanneer Bets siek word en in' $n$ koorsbeswyming gaan, ervaar sy verhoogde sensoriese belewings (haar reuksintuig raak byvoorbeeld verfyn) en "vir'n paar dae lank lê sy [soos die spinnekop - EL] toegespin en bewegingloos. Sy droom in haar metamorfoserende toestand van die Rivier van Goud, van die Verbode Dorp" (86, my kursivering).

Die motto by hoofstuk 1 van Deel 1 in die novelle is ' $n$ verifieerbare wetenskaplike stelreël: "Indeterminacy affects all phenomena, great and small, but its significance is usually confined to the micro-physical domain." Die mikrofisika verwys na'n studie van organismes wat slegs mikroskopies waarneembaar is en saamgelees met dié motto, word die teks (soos'n spinnerak of "entangled bank" in die Victoriaanse konteks) ook'n komplekse netwerk waarbinne die leser uitgelok word om verbande te lê (Stander). Stander vertolk dus dié openingswoorde nie bloot as "simptomaties van die onbepaaldheid en onbegrensdheid van die teks self nie", maar ook as leesleidraad wat saam met die advies in die volgende paragraaf deur die leser ingespan moet word: “En in geval dat sy vergeet het (dink sy)—met haar oog so stip op die pad, haar gegroefde wenkbrou en haar gepelsde oor-hoor sy hoe belangrik dit is om onderskeidings te tref en verbande te lê." (86)

Die wetenskaplike toonaard word verder bevestig in die keuse van' $n$ verdere motto by hoofstuk 12 in Deel 2: "Vegetal Plants, Sensible Beasts, Rational Men," wat verwys na Richard Burton se ensiklopediese teks oor kognitiewe gedrag, The Anatomy of Melancholy (1621). Grondliggend aan Burton se kognitiewe model is die "conception of the mind and body as total organism" (Herreros). Volgens Burton is alles in die menslike liggaam gekoppel aan ' $n$ "spirit/humour" en hy onderskei drie tipes (naamlik "natural, vital and animal") wat elkeen respek- 
tiewelik aan die lewer, hart en brein verbind word. Vergelyk ook die vier humores of liggaamsvogte uit die Oudheid en let in hierdie verband ook op die ooreenstemmende Jungiaanse persoonlikheidseienskappe van denke, intuïsie, sensasie en gevoel wat hiermee korreleer (Van Coller en Van den Berg 340).

Soos by Klaaglied vir Koos word alle plant- en dierspesies by implikasie weer op dieselfde ontologiese vlak geplaas. Ook in erf is daar talle voorbeelde waar die een objek (voortdurend aan't aanpas en verander) in terme van'n ander spesie beskryf word: Agnes wonder byvoorbeeld “of sy reeds ' $n$ vlermuis of 'n padda of 'n ding geword het, en of sy nog uit die grot of die ondergrond kan ontsnap" (37). Die bruin plakkers word vergelyk met "kewers in hout, soos die onsigbare wurm wat vlie in die nag" (68).

Die Winterbach-beheptheid met oorspronge (en spesifiek die geologie van die aarde) resoneer weer in die herinnerde besoek van Bets en haar man aan 'n afgesonderde semi-woestynstreek in die binneland waar die skaliesteen, wanneer dit oopgebreek word, "soos die oop blaaie van'n boek [...] die fyn fossiele van die blare en die paddas blootlê." (61)

Aan die einde van die verhaal beweer Bets dat sy tuisgekom het: "Nou weet ek ek is tuis. Ek is bewerig en onseker. Nadat ek my groei soos'n reis deur die nou opening van die serviks genavigeer het. Uit my kokon na my transformasie." (70, my kursivering) Dié transformasie word narratologies voltrek wanneer die ekologiese balans van haar erf herstel word; wanneer sy ten slotte sluiting vind en haar tuin tot'n mate "terugwen":

Dit is algeheel stil in die tuin; die hitte sluit dit af van die geluide daarbuite. Net die ryk vegetale lewe luier sag soos ' $n$ groot enjin. Maar geleidelik raak sy bewus van ' $n$ egalige frekwensie, nie hoorbaar nie, eerder opgevang deur haar senu-eindpunte. [...] Sy spit verder. Sy spit dieper. Die grond het 'n klammer, ryker gevoel. Nooit terugwen wat ons verloor het nie. As ons gelukkig is, miskien dele van onsself waarvan ons afgesny was, herwin. Met aansienlike moeite. Op die straf van dood. 'n Soort balans herstel. (100-01)

Die voorkeur vir wetenskaplike benoeming skemer weer, soos in die debuut, deur wanneer plantsoorte dikwels met hulle Latynse spesiename soos Rhus, Burkea en Eckbergia benoem (en daarmee dus ook geappropieer) word. Die lewe op die erf word in soortgelyke terme beskryf: "Die werf word skynbaar uitsluitlik bewoon deur die ordes Orthoptera, Isoptera, Mantodea, Diptera, Lepidoptera, Coleoptera, Blattaria (afskuwelike goggas laasgenoemde.)." (60) Dié vermelde ordes verwys in volgorde respektiewelik na sprinkane, termiete, bidsprinkane, vlieë, motte en skoenlappers, besies en kokkerotte. Dit is opvallend dat die wetenskaplik verifieerbare klassifikasie van insekordes in die romans telkens, soos in die voorafgaande voorbeeld, opgevolg word met'n platter en volkse verduideliking (asof die wetenskaplike feit vir die leser ook in leketerme toeganklik gemaak word). 
Die wetenskaplike sfeer van die teks word herbevestig in die intellektuele gesprekke tussen die vroulike hoofkarakter Bets en haar vriend, Harie:

Terwyl hulle eet, verduidelik hy vir haar die verhoudings tussen xileem-morfologie en ekologie, die aspekte van die anatomie van hout en die altitudinale en latitudinale verspreiding van ekologiese kategorieë. (Die vordering in die studieveld is traag, sê hy.) Hy wys vir haar hoe sekondêre xileemelemente ontleed word deur 'n aanduiding van korter vaatdele, dunner vate, korter en dunner vesels, en die frekwensie van helikale verdikkings in die vaatmure. (17)

Dié wetenskaplike taalregister word ten onregte deur Van Zyl (12) gekritiseer wanneer sy bevind dat die funksionaliteit van dié "akademiese taal" uit pas is met die milieu. Haar uitspraak hou egter nie rekening daarmee dat die wetenskaplike verwysings in sowel Klaaglied vir Koos as erf'n integrale deel van die romanstruktuur vorm nie.

\section{Gevolgtrekking: 'There is grandeur in this view of life'}

Uit die voorafgaande ondersoek na evolusionêre patrone in die Winterbachtweeluik, behoort dit nou duidelik te blyk dat die wetenskap (en spesifiek die evolusieleer van Darwin) op boeiende wyse in die twee Winterbach-tekste vergestalt word. Haar uitbeelding van' $n$ Darwinistiese wêreldbeskouing geskied onder meer deur 'n verbeeldingryke aanwending van die "entangled bank"metafoor. Dié metafoor van'n oorbegroeide rivieroewer is destyds deur Darwin in The Origin of Species benut om die proses van natuurlike seleksie as aandrywer van evolusie op 'n toeganklike manier te verduidelik. Dit is juis hierdie presiese metafoor wat ook deur Winterbach ontgin word in haar beskrywing van romanruimtes (stad, dorp, erf en tuin) waar 'n magdom verskillende, maar interafhanklike karakters en spesies'n oorlewingstryd voer.

'n Gestalt van Darwinistiese beginsels, soos deur Levine (Darwin) onderskei, is deurgaans in die bostaande evokritiese lesing van die tweeluik aangetoon. Die oogmerk was om te bewys dat die vroeëre werk van Winterbach ook alreeds'n Darwinistiese wêreldbeskouing vergestalt en dat dié vergestalting artistiek verantwoordbaar is. Winterbach se herhaalde benutting van die volgende Victoriaanse Darwinistiese merkers is met behulp van eksemplariese teksvoorbeelde in die bespreking hierbo aangetoon: die fiksionalisering van 'n empiries-wetenskaplike wêreldbeeld; die natuurhistoriese instelling asook die invoeging van talle betekenisdraende newetekste wat daardie instelling bestendig;' $n$ beheptheid met oorsprong, evolusie en (inkantiewe) benoeming van spesie; die gelykstelling tussen mens en insek/dier; die "invloed" van natuurlike voorwerpe; asook die romanmatige poging om wetenskaplike kennis vir nie-wetenskaplikes toegankliker te maak (Brantlinger en Thesing; Paradis en Postlewait). 
Tipiese Victoriaanse leimotiewe soos die mot, wurm, spinnekop, die biologiese sel, spinnerak of weefsel, die aarde as lewende organisme en "die liggaam as anatomiese preparaat" is eweneens aangetoon (Gouws). In die fiksionaliseringsproses het daar' $n$ idiosinkratiese semantiese veld (of eie woordeskat) ontstaan met die frekwente gebruik van kernwoorde soos "metamorfoseer", "groei", "stadium", "oorsprong", "kokon", "papie", "mot" en "transformasie" ten einde dié wetenskaplike wêreldbeskouing te bestendig. Die evolusionêre konsepte ondersteun ook op metaforiese vlak die psigiese transformasie van twee alleenstaande vrouekarakters (ongetroud of tydelik geskei van'n man) wat op'n stedelike erf met sekere bestaansvrae worstel.

Die tendens om die vrouekarakters te bemagtig deur aan hulle progressiewe beheer oor die wetenskapsdiskoers te gee namate hulle van hulle mans of minnaars ontvoog word, verraai ook die genderkritiek wat hier in die manipulering van'n wetenskaplike register geleë is. In die tweeluik word die Darwinistiese beginsel dat hiërargiese grense tussen menslike karakters en ander biologiese spesies uitgewis word, ook treffend gefiksionaliseer. Winterbach se strategie om grense tussen spesies te bevraagteken, vertoon ook opvallende ooreenkomste met die tipies negentiende-eeuse kongruensie wat daar destyds tussen menslike en niemenslike gemeenskappe getref is. Die mens-insek-gelykstelling is die mees voor die hand liggende voorbeeld hiervan, maar talle ander gevalle is in die bespreking hierbo uitgelig waar mense en ander biologiese spesies ook as gelyke lede van die diereryk uitgebeeld word. Die immerteenwoordigheid van insekte word volgens Gouws ook onder meer geassosieer met "nietigheid, kortstondigheid, ontbinding, die ondergrondse en die grond self" (17). Hy meen dat hierdie konstante wetenskaplike verwysing na dit wat heel klein is (insekte) asook dit wat heel groot is (die kosmos) 'n leegheid of afwesigheid op mesovlak aandui: oor samelewings (wat hy as' $n$ tussengebied aantoon) is daar by implikasie dus geen vergelykbare wetenskaplike kennis moontlik nie en daarom bly slegs geskiedenis(se) oor.

Soos in die klassieke Victoriaanse romans (en die eietydse permutasies daarvan), is die evolusionêre bevoorgronding en benoeming van spesies 'n prominente kenmerk in die twee tersaaklike tekste. Die simboliese waarde van 'n eksakte benoemingsaksie word immers deur sowel Winterbach (in La Vita) as Byatt (76) beklemtoon. Laasgenoemde beskryf die inkantiewe benoemings in (neo-) Victoriaanse tekste soos volg: "scientifically and poetically. Phylum, Class, Order, Genus, Species" - 'n beskrywing wat strook met die uitgebreide inventarisse in die twee voorbeeldtekste. Jansen (734) sonder ook dié betrokke gebruik van Latynse en wetenskaplike spesiename in Winterbach se oeuvre uit en verklaar dat die gebruik van 'n alternatiewe taalregister (soos hierdie vorm van wetenskaplike benoeming) ' $n$ poging van romankarakters is om hulle beperkte en gemarginaliseerde posisies te oorstyg; om "ten spyte van belemmerende faktore uit [te] reik 
na organiese transformasie" (734). Die didaktiese strewe (of "edifying discourse", aldus Winterbach), naamlik om wetenskaplike kennis ook aan nie-wetenskaplikes te dissemineer, blyk voorts uit die feit dat sulke wetenskaplike benamings deurgaans versag word met meer toeganklike, nie-wetenskaplike verduidelikings.

Hierdie Darwinistiese lewensuitkyk het weliswaar in die laat-Victoriaanse naturalistiese roman (en ook ander naturalistiese literatuur) tot' $n$ gees van ontnugtering gelei. In die tekste onder bespreking is daar dan ook beduidende naturalistiese eggo's wat veral met verwysing na die gekwelde karakters aantoonbaar is: skuldgevoelens, angs, depressie, magteloosheid, onvermoë om traumatiese verledes te verwerk, selfmoordneigings asook'n preokkupasie met noodlot en sterflikheid. Die besef dat die mens'n produk van erflikheid en omgewing is wat geen beheer oor natuurwette het nie, dra verder by tot die diepe gevoel van naturalistiese disillusie by vele karakters in die tweeluik. Hierdie gedagte word op teksvlak vergestalt in die talle beskrywings van onwillekeurige fisiologiese prosesse wat in die individuele karakters (maar ook kollektief) plaasvind. Die romankarakters is dus diep onder die indruk van hulle eie sterflikheid en wend deurentyd pogings aan om hulle verganklikheid te besweer deur te versamel, te klassifiseer, uit te stal, te bewaar en te benoem.

Vir Gouws (12) manifesteer hierdie disillusie in die lewens van die gekwelde protagoniste by uitstek in die voorkeur vir konkawe ruimtes: tonnels, holtes, gate en mierneste. Dié ruimtes wys weer heen na die verborgenhede en ondergrondse wat so prominent figureer in die woord- en beeldtekste van Winterbach. Na my oordeel onderbeklemtoon Gouws in sy argument die konstante verwondering aan die natuurlike wêreld wat uit die tekste onder bespreking blyk. In hierdie spesifieke opsig word daar dus tóg afgewyk van die somberheid wat so kensketsend is van die klassieke naturalistiese roman. Die verwondering aan en waardering vir natuurlike voorwerpe wat uit die twee Winterbach-tekste straal, strook egter met Levine (Darwin) se vertolking van'n romantiese Darwin wat verbysterd voor die eindeloosheid van evoluerende vorme staan wanneer hy in die slotparagraaf van On the origin of species verklaar: "There is grandeur in this view of life".

Winterbach se uitbeelding van 'n Darwinistiese wêreldbeskouing (en meegaande fassinasie met die natuurgeskiedenis) vlerk dus aan by die Victoriaanse en neo-Victoriaanse verteltradisies, wat'n soortgelyke verankering in Darwinistiese idees veronderstel. In hierdie bepaalde opsig sluit die eksemplariese tekste dus aan by literêr-historiese kategorieë soos Darwinistiese romans (Chapple), natuurhistoriese romans (Shuttleworth 253-68.), natuurgeskiedenisse (Byatt), die naturalistiese roman en selfs die retro- of neo-Victoriaanse romantradisie (Lemmer, "Ingrid Winterbach"). 


\section{Geraadpleegde bronne}

Beer, Gillian. Darwin's Plots. Evolutionary Narrative in Darwin, George Eliot and Nineteenth-century Fiction. Cambridge: CUP, 2000.

Brantlinger, P. en W.B. Thesing. A Companion to the Victorian Novel. Oxford: Blackwell, 2002.

Brink, André P. “Klaaglied vir Koos is van die beste prosa in jare." Rapport 20 Jan. 1985, 14. . "n Novelle vol uitdagings vir die ernstige leser." Rapport 21 Des. 1986, 10.

Britz, E.C. "Met'n anti-burgerlike en artistieke oog." Die Burger 12 Mrt. 1987, 9.

Brockman, John. The Third Culture. New York: Simon \& Schuster, 1995.

Byatt, A.S. On Histories and Stories. Selected Essays. Cambridge: Harvard UP, 2000.

Chapple, J.A.V. Science and Literature in the Nineteenth Century. London: Macmillan, 1986.

Darwin, Charles. The Origin of Species by means of Natural Selection or the Preservation of Favoured Races in the Struggle for Life. 1859. Middlesex: Penguin, 1983.

De Vries, Fred. The Fred de Vries Interviews: from Abdullah to Zille. Johannesburg: Wits UP, 2008.

Glendening, John. The Evolutionary Imagination in Late-Victorian Novels. An Entangled Bank. Burlington: Ashgate, 2007.

Gouws, Andries. "Ingrid Winterbach as skrywer en as beeldende kunstenaar-enkele beskouings." Stilet 20.1 (2008): 8-42.

Gutleben, Christian. Nostalgic Postmodernism. The Victorian Tradition and the Contemporary British Novel. Amsterdam: Rodopi, 2001.

Hambidge, Joan. “Om boodskap en aanbod 'n belangrike prosawerk." Die Vaderland 4 Febr. 1985, 11.

Herreros, G. "El sitio de la Melancholia. Robert Burton: The Anatomy of Melancholy (1621)." 12 Sept. 2007. <http://www.herreros.com.ar/melanco/anatomy.html>.

Jansen, Ena. "Lettie Viljoen/Ingrid Winterbach (1948- )." Red. H.P. van Coller. Perspektief en profiel: 'n Afrikaanse literatuurgeskiedenis, Deel 2. Pretoria: J.L. Van Schaik, 1999, 733-45.

Kannemeyer, J.C. Geskiedenis van die Afrikaanse literatuur (1652-2004). Kaapstad: Human \& Rousseau, 2005.

Kirchknopf, A. “(Re-)workings of Nineteenth Century Fiction: Definitions, Terminology, Contexts." Neo-Victorian Studies 1.1 (2008): 53-80.

Knight, David. The Age of Science: the Scientific World View in the Nineteenth Century. Oxford: Basil Blackwell, 1986.

Kucich, John. "Scientific ascendancy." Reds. P. Brantlinger en W.B. Thesing. A Companion to the Victorian Novel. Oxford: Blackwell, 2002, 119-36.

La Vita, Murray. “Nie diép genoeg nie." Beeld By 27 Mrt. 2010, 7.

Le Roux, A. "Goed begin en baie gewin." Die Burger 18 Apr. 1985, 9. . "Die lekkerkry met 'n sug afgewissel." Beeld 20 Mei 1985, 8.

Lemmer, Erika. Persoonlike gesprek met Ingrid Winterbach. Durban, 28 Mrt. 2004. . "Ingrid Winterbach, 'n derde kultuur en die neo-Victoriaanse romantradisie (1984-2006)". D.Litt, U Suid-Afrika, 2010.

Levine, George. red. One Culture: Essays in Science and Literature. Wisconsin: The U of Wisconsin P, 1987. . Darwin and the Novelists: Patterns of Science in Victorian Fiction. Cambridge: Harvard UP, 1988 . "Foreword". Red. G. Beer. Darwin's Plots. Evolutionary Narrative in Darwin, George Eliot and Nineteenth-century Fiction. Cambridge: CUP, 2000, 1-9.

. Darwin loves you. Natural Selection and the Re-enchantment of the World. Princeton: Princeton UP, 2006.

Malan, C. "Neef Chrisjan wat so lag." De Kat 31 Jul. 1991, 8.

Paradis, J. en T. Postlewait. Victorian Science and Victorian Values: Literary Perspectives. New York: The New York Academy of Sciences, 1981.

Shaffer, Elaine, red. The Third Culture: Literature and Science. Berlin \& New York: Walter de Gruyter, 1998.

Shuttleworth, Sally. "Natural History: the Retro-Victorian Novel." Red. E. Shaffer. The Third Culture: Literature and Science. Berlin \& New York: Walter De Gruyter, 1998, 253-68.

“Writing Natural History: 'Morpho Eugenia."” Reds. A. Alfer and M. Noble. Essays on the Fiction of A.S. Byatt. Imagining the Real. Londen: Greenwood Press, 2001, 147-61.

Stander, Christelle. "'n Ontsluiting van enkele ideologiese aspekte in die teks erf van Lettie Viljoen." BA Hons skripsie, U Wes-Kaapland, 1988. 
'AN ENTANGLED BANK': Evolusionêre patrone in Klaaglied vir Koos en erf

Van Coller, H.P. red. Perspektief en Profiel: 'n Afrikaanse Literatuurgeskiedenis. Deel 2. Pretoria: J.L. van Schaik, 1999.

en Van den Berg, C. “Trauma, verlies en die semiotiese bewussyn in Karolina Ferreira en Niggie van Ingrid Winterbach." Stilet 21.2 (2009): 29-52.

Van den Heever, A.J. 2010. "Toevalligheid in Ingrid Winterbach se Die boek van toeval en toeverlaat: Interpretasies van die roman met die fokus op die tema van kontingensie." MA-tesis, U Stellenbosch.

Van der Vyver, Maritha. "Kort en kragtig". Sarie 30 Julie 1986: 11.

Van Vuuren, Helize. "Alles vloei en niks hou stand: 'n verkenning van Ingrid Winterbach se Die boek van toeval en toeverlaat." Stilet 20.1 (2008): 163-77.

Van Zyl, A. "Aktuele verhaal oor swartes raak diep." Die Volksblad 6 Des. 1986, 12.

Venter, Leon. "'n Prestasie in die jonger prosa." Die Volksblad 18 Jan. 1986, 10.

Viljoen, Lettie (ps. Ingrid Winterbach). Klaaglied vir Koos. Johannesburg: Taurus, 1984. . erf. Johannesburg: Taurus, 1986.

. Belemmering. Johannesburg: Taurus, 1990.

. Karolina Ferreira. Kaapstad: Tafelberg, 1993.

. "U is 'n bodemlose put. Lettie Viljoen oor metafiksionele kwessies." Die Suid-Afrikaan 47 (1994): 40. . Landskap met vroue en slang. Kaapstad: Human \& Rousseau, 1996.

Viljoen, Louise. "Postcolonialism and Recent Women's Writing in Afrikaans." World Literature Today 70.1 (1996): 63-72. <http://www.agape.co.za/ingrid/klaaglie.htm>

. "Die boek van toeval en toeverlaat: 'n rykdom van verbeelding, besinning en toespeling". LitNet. 2007. <http//:www.litnet.co.za/cgi-bin/giga.cgi?cmd= cause_dir_news_item \&cause_id $=1270>$.

Winterbach, Ingrid. Buller se plan. Kaapstad: Human \& Rousseau, 1999. 